\title{
Increasing Water Use Efficiency Comes at a Cost for Norway Spruce
}

\author{
Tanja GM Sanders ${ }^{1,2, *}$, Ingo Heinrich ${ }^{3}$, Björn Günther ${ }^{4}$ and Wolfgang Beck ${ }^{1}$ \\ 1 Johann Heinrich von Thuenen Institute, Federal Research Institute for Rural Areas, Forestry and Fisheries, \\ Institute of Forest Ecosystems, Alfred-Moeller-Str. 1, 16225 Eberswalde, Germany; \\ wolfgang.beck@thuenen.de \\ 2 Institute for Botany and Landscape Ecology, University Greifswald, Grimmer Str. 88, \\ 17487 Greifswald, Germany \\ 3 GFZ, German Research Centre for Geosciences, Department 5, Geoarchives, Telegrafenberg, 14473 Potsdam, \\ Germany; heinrich@gfz-potsdam.de \\ 4 Technische Universität Dresden, Institute of Forest Utilization and Forest Technology, \\ Chair of Forest Utilization, Piennerstr. 19, 01735 Tharandt, Germany; Bjoern.Guenther@tu-dresden.de \\ * Correspondence: tanja.sanders@thuenen.de; Tel.: +49-3334-3820-339
}

Academic Editor: Timothy A. Martin

Received: 30 August 2016; Accepted: 21 November 2016; Published: 28 November 2016

\begin{abstract}
Intrinsic water use efficiency $\left(\mathrm{WUE}_{\mathrm{i}}\right)$ in trees is an indication of the ratio of carbon assimilation to the rate of transpiration. It is generally assumed that it is a response to water availability. In agricultural research, the question of drought tolerance by increased $\mathrm{WUE}_{\mathrm{i}}$ has been well studied. In general, the increase is a trade-off for productivity and is therefore not desired. For forest trees, this question is less clearly understood. Using stable carbon isotopes derived from tree rings combined with productivity as the product of the annual growth increment and annual density measurements, we compared the change in $W_{U} E_{i}$ over a 15 year period. While $W_{U} E_{i}$ increased over this period, the productivity decreased, causing an opposing trend. The gradient of the correlation between $\mathrm{WUE}_{\mathrm{i}}$ and productivity varies between provenances and sites. Counterintuitively, the populations at the drier site showed low $\mathrm{WUE}_{\mathrm{i}}$ values at the beginning of the investigation. Slopes vary with the provenance from Poland showing the least decline in productivity. In general, we found that a decline in productivity aligned with an increase in $\mathrm{WUE}_{\mathrm{i}}$.
\end{abstract}

Keywords: water use efficiency; provenance trial; dendroecology

\section{Introduction}

Foresters have a major interest in the annual growth of trees [1], which is believed to increase due to globally rising $\mathrm{CO}_{2}$ concentrations [2]. This might be due to changes in either the photosynthesis rate or a lowered demand for water [3], explained by a $\mathrm{CO}_{2}$ fertilisation effect [4]. Studies on the effect of $\mathrm{CO}_{2}$ on forest productivity are, however, inconclusive, with productivity increasing in young trees but a levelling off effect is seen in mature trees [5]. Some studies have detected a positive effect at sites with limited water supply [6], while others state the opposite [7]. Further uncertainty is linked to the effect of increasing $\mathrm{CO}_{2}$ on water use efficiency (WUE) [8]. Keenan et al. [9] observed an increase of WUE in temperate and boreal forests. The link between an increase of $\mathrm{CO}_{2}$, WUE, and productivity, while undoubtedly important with respect to growth and carbon sequestration models, is not fully conclusive [1]. This is likely due to the interaction of the effects of water availability, temperature [10], and tree age [11]. Additionally, air pollutants, namely sulphur, can inhibit growth [12] and influence $\delta^{13} \mathrm{C}$ values [10]. While there has been a decrease in, especially sulphur, deposition since the 1970s in most parts of Europe [13], values derived from the intensive forest monitoring still reach values between 8 and $16 \mathrm{~kg} / \mathrm{ha}$ (mean of the years 2012-2014; [14]) in areas of central Europe. 
One of the studies investigating stand-specific correlations of intrinsic water use efficiency $\left(W_{U} E_{\mathrm{i}}\right)$ and productivity found that against expectations, $\mathrm{WUE}_{\mathrm{i}}$ increased while annual increment did not [15]. The same study highlights that there were no clear trends on a larger scale. This again points in the direction of a local environmental factor determining the ecophysiological response and interaction of the trees with the environment; Monclus et al. [16] found a large variance even on the level of genotype, in line with Farquhar et al. [17,18], stating a genetic effect on carbon discrimination at a stomatal level. On the whole, studies exist which support a link between $\mathrm{CO}_{2}$ fertilisation and changes in WUE [19], but the scale and magnitude is not yet clear.

WUE for trees can be reconstructed using the stable isotopes of carbon $\left({ }^{13} \mathrm{C} /{ }^{12} \mathrm{C}\right)$. Through the stomata of the leaves, trees control the gas exchange of water vapour, $\mathrm{CO}_{2}$, and $\mathrm{O}_{2}$ between the inside tissue and the outside environment. Closure of the stomata during dryer conditions results in sub-optimal concentrations of $\mathrm{CO}_{2}$ in the intercellular spaces, thereby limiting water losses, but also potentially decreasing the rate of photosynthesis. Fardusi et al. [1] hypothesised that if higher WUE is linked to increasing photosynthesis, the growth should increase. While they were able to demonstrate a clear correlation for the two parameters in their meta-analysis, it was not constant across environments. The range of response as well as the baseline of WUE is likely specific to the genotype, but only part of the response potential is used depending on the given environmental factors. We therefore postulate an increase of WUE above an annual $0.3 \%$ to $0.5 \%$, likely due to $\mathrm{CO}_{2}$ changes [20], as an indication of stress likely due to water shortage. Following the theoretical framework of Silva and Anand [21], we link tree growth to $\mathrm{WUE}_{\mathrm{i}}$. In order to understand the difference in plasticity linked to individual and phenotypic responses, we investigated the changes in $\mathrm{WUE}_{\mathrm{i}}$ of three Norway spruce (Picea abies [L.] Karst) provenances at two sites in Saxony, Germany over a 15-year period and link it to annual stem growth increments as well as annual mean density measurements.

\section{Materials and Methods}

The study sites are located in the south-eastern region of Germany at the border to the Czech Republic. Two sites, with contrasting environmental conditions, were planted with different Norway spruce (Picea abies [L.] Karst) provenances in the 1970s. The site Borstendorf receives a medium amount of precipitation ( $861 \mathrm{~mm} /$ year) and is an example of a suitable planting site for spruce (Figure and Table). Hohenleipisch on the other hand receives $553 \mathrm{~mm}$ a year but is influenced by often stagnating conditions caused by regular flooding in winter and early spring. Therefore, the root system developed rather shallow preventing the trees from reaching deeper water sources in summer. Overall six provenances were sampled following standard dendroecological methods [22]. Two cores were extracted using an increment borer from 16 to 20 trees at the respective sites. Based on the individual chronologies, the provenances best representing their respective site (Rycerka in Borstendorf and Reinhardtsdorf in Hohenleipisch) and the ones with the lowest mean annual increment (Reinhardtsdorf in Borstendorf and Nementschina in Hohenleipisch) were selected. Of those four provenances, five trees each were re-sampled taking two additional cores for stable carbon isotope and density analysis.

The samples were analysed individually with an annual resolution of $\delta^{13} \mathrm{C}$. Tree rings were split manually with a scalpel using a stereomicroscope, and the $\alpha$-cellulose was extracted following the chemical method based on the use of sodium hydroxide and sodium chlorite [23]. From the wood samples $\alpha$-cellulose is extracted as the different components of wood vary in their isotopic value [24]. The ${ }^{13} \mathrm{C} /{ }^{12} \mathrm{C}$ isotope ratios were measured as $\mathrm{CO}_{2}$ by combusting the $\alpha$-cellulose samples in an elemental analyser (Model NA 1500; Carlo Erba, Milan, Italy) coupled via an open split to an isotope ratio mass spectrometer (Micromass Optima, Ltd. Manchester, UK) operating in continuous flow mode. Sample replication resulted in a precision of better than $\pm 0.1 \%$ for $\delta^{13} \mathrm{C}$ values. The isotope ratios are given in the conventional delta $(\delta)$ notation, relative to the Vienna Pee Dee Belemnite (VPDB) standard $\left(\delta^{13} \mathrm{C}\right)$. WUE $\mathrm{W}_{\mathrm{i}}$ was calculated according to Farquhar et al. [18]. 
Density measurements followed standard methodology [25]. Cores were cut to a thickness of $1.1 \mathrm{~mm}$ using a twin blade (Dendrocut-Walesch Electronics, Effretikon, Switzerland). Resin and other organic compounds were subsequently removed by immersion in warm $95 \%$ alcohol for six hours. Samples were acclimatised for $24 \mathrm{~h}$ to $65 \%$ air humidity and $20{ }^{\circ} \mathrm{C}$ prior to $\mathrm{X}$-ray exposure. X-ray exposure (Baltograph, Baltau, Oupeye, Belgium) was 55 min using the film material Agfa MICROVISION ${ }^{\circledR}$ - CI. For the compilation and quantification, the Densiometer Dendro2003 (Walesch Electronics, Effretikon, Switzerland) was used. Productivity was calculated as the annual product of density and tree-ring width. Statistical analyses were performed using SigmaPlot (V. 12, Systat Software GmbH, Erkrath, Germany).

\section{Results}

Trees on the near-optimum site (Borstendorf, Germany) grew well, while the trees on the less favourable site (Hohenleipisch, Germany) showed increasing signs of stress. After reaching maturity, conditions worsened at the latter plot due to competition, leading to generally lower growth rates at this plot (Figure S2). Mean early wood density (MEWD) increased (Figure 1a) at both sites in the investigation period from 1996 to 2011, with a levelling off of the MEWD in Hohenleipisch over the last three years. For this parameter, individual trees did not respond homogenously within the provenance or plot.

For all four populations, an increase in $\mathrm{WUE}_{\mathrm{i}}$ over the 15 year investigation period was visible (Figure 2). The increase was strongest for the provenance Rheinhardtsdorf in Hohenleipisch with a significant incline with the linear trend of $0.75(p<0.05)$, and weakest for the provenance Rycerka in Borstendorf (0.16). The provenance Nementschina in Hohenleipisch showed the second highest incline with $0.45(p<0.1)$, while the provenance Rheinhardtsdorf in Borstedorf had the third highest incline (0.33).
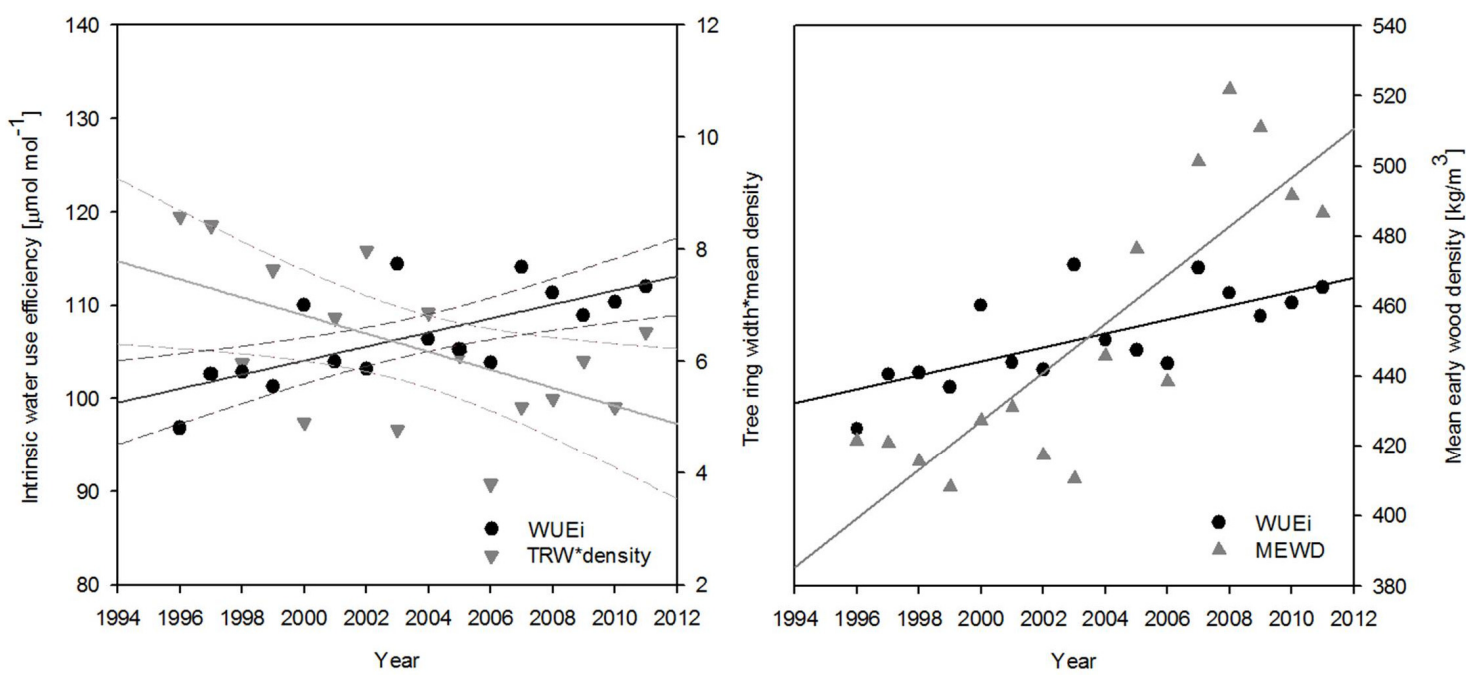

Figure 1. Trends of water use efficiency and tree-ring width multiplied by mean density as an indicator of productivity (left) and mean early wood density (right) over the 15 year investigation period for the Rheinhardsdorf provenance in Hohenleipisch.

In contrast to the growth responses, differences in the mean $W_{U E} E_{i}$ were independent of the site and provenance. These statistically significant differences between the provenances of Nementschina and Reinhardtsdorf in Hohenleipisch, and of Reinhardtsdorf and Rycerka in Borstendorf (Figure 2) are determined by both ecological site factors and genetic variability. Focusing on the Rheinhardtsdorf provenance, trees at the near-optimum site (Borstendorf-bottom) did show an annual variation in $\mathrm{WUE}_{\mathrm{i}}$, but no general increase. At the Hohenleipisch (top) site, which experienced regular drought events and had limited resources, we detected a significant increase over the same period. 
The significant intra-provenance difference when comparing the two sites confirmed the results of the growth analysis. Hohenleipisch, the site with a high ground water table, exhibited generally lower values of WUE compared to the Borstendorf site with intermediate rainfall. The range was highest for the Reinhardtsdorf provenance at Hohenleipisch, which also showed the lowest values in 1996 with high fluctuations. It is followed by Nementschina at the same site. Smaller ranges occurred at the Borstendorf site. Here the significant difference between the provenances is apparent.
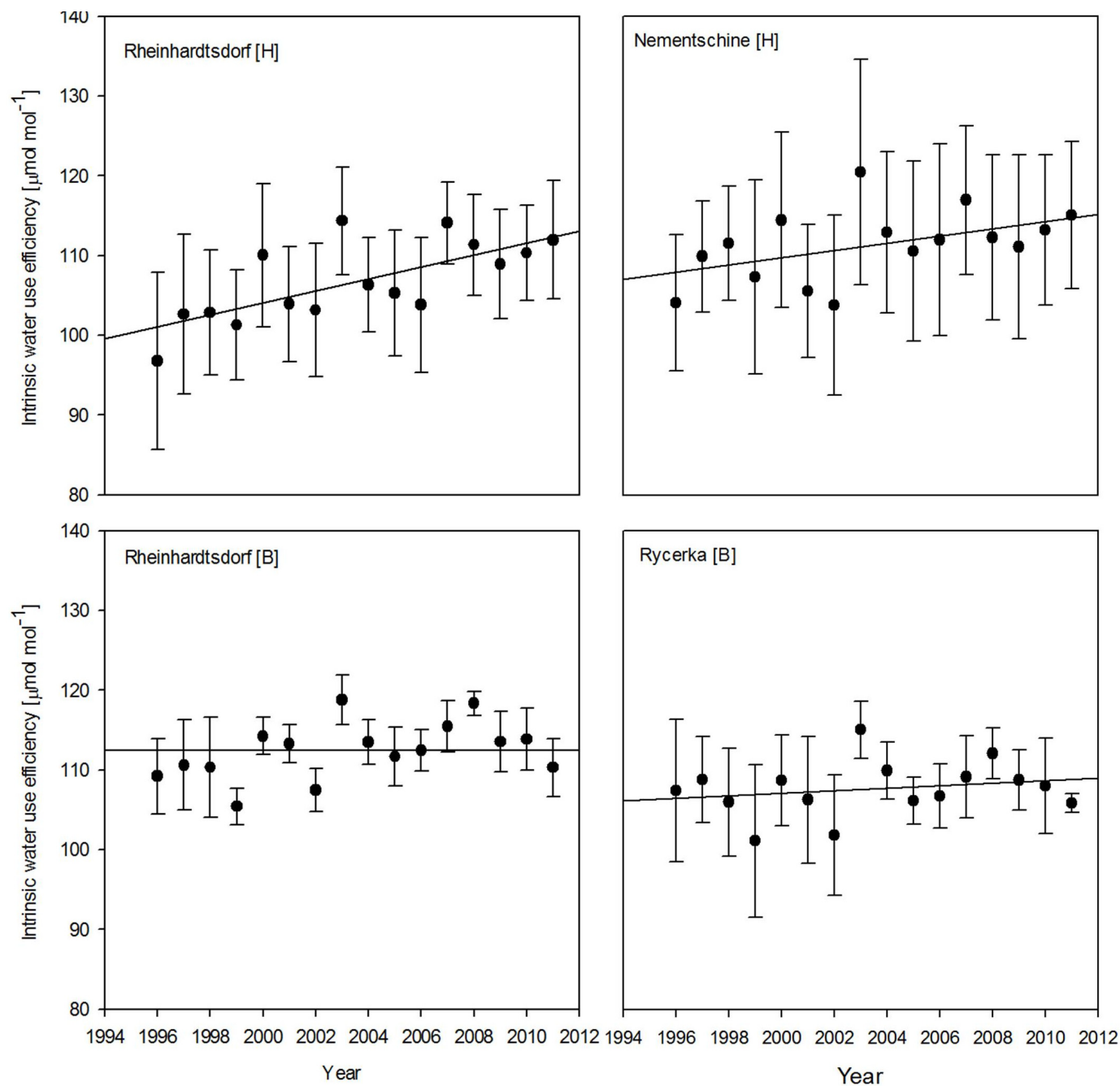

Figure 2. Trends in water use efficiency over the 15 year investigation period for all samples. Error bars indicate the variance between the five individual trees for each population.

For all sites, the annual increment declined within the same period, with the highest productivity for all populations reached between 1996 and 1999. The following period until 2006 was marked by a decline followed by a levelling off until the end of the investigation in 2011. Figure 3 shows the opposing trends of $\mathrm{WUE}_{\mathrm{i}}$ and productivity over the whole period using the example of the Reinhardtsdorf provenance in Hohenleipsch as well as the increase of MEWD over the same period. This shows the independent response of early wood formation and the overall annual growth.

Combining productivity with $\mathrm{WUE}_{\mathrm{i}}$ in the respective years showed a significant trend (Borstendorf: $p<0.05$ and Hohenleipisch: $p<0.01$ ) at both sites for the Reinhardtsdorf provenance. The trend for the Nementschina provenance was also significant $(p<0.01)$. The only provenance with an insignificant trend was Rycerka (Figure 4), thus showing the linkage between low productivity and an increase in $W_{U E}$. Focusing on known drought years, e.g., 2003, the increased $W_{U E}$ in the respective 
year, followed by a decline in the following year (2004) expressed the fast and specific response to drought stress.

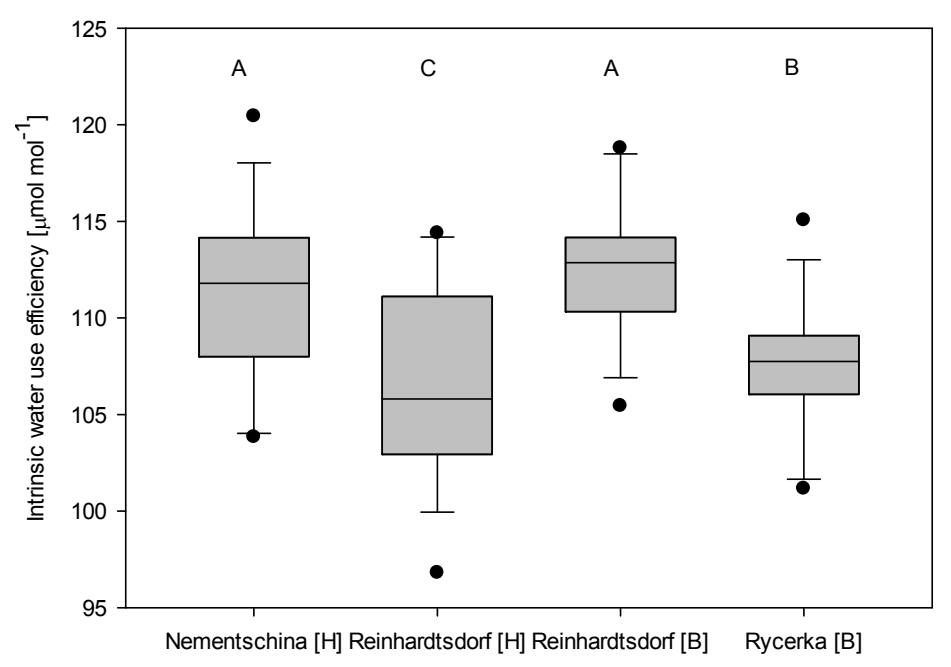

Figure 3. Mean intrinsic water use efficiency of the respective provenances and sites $(\mathrm{H}=$ Hohenleipisch; $\mathrm{B}=$ Borstendorf); Different letters indicate statistically significant (Bonferroni $t$-test, $p<0.05$ ) differences.
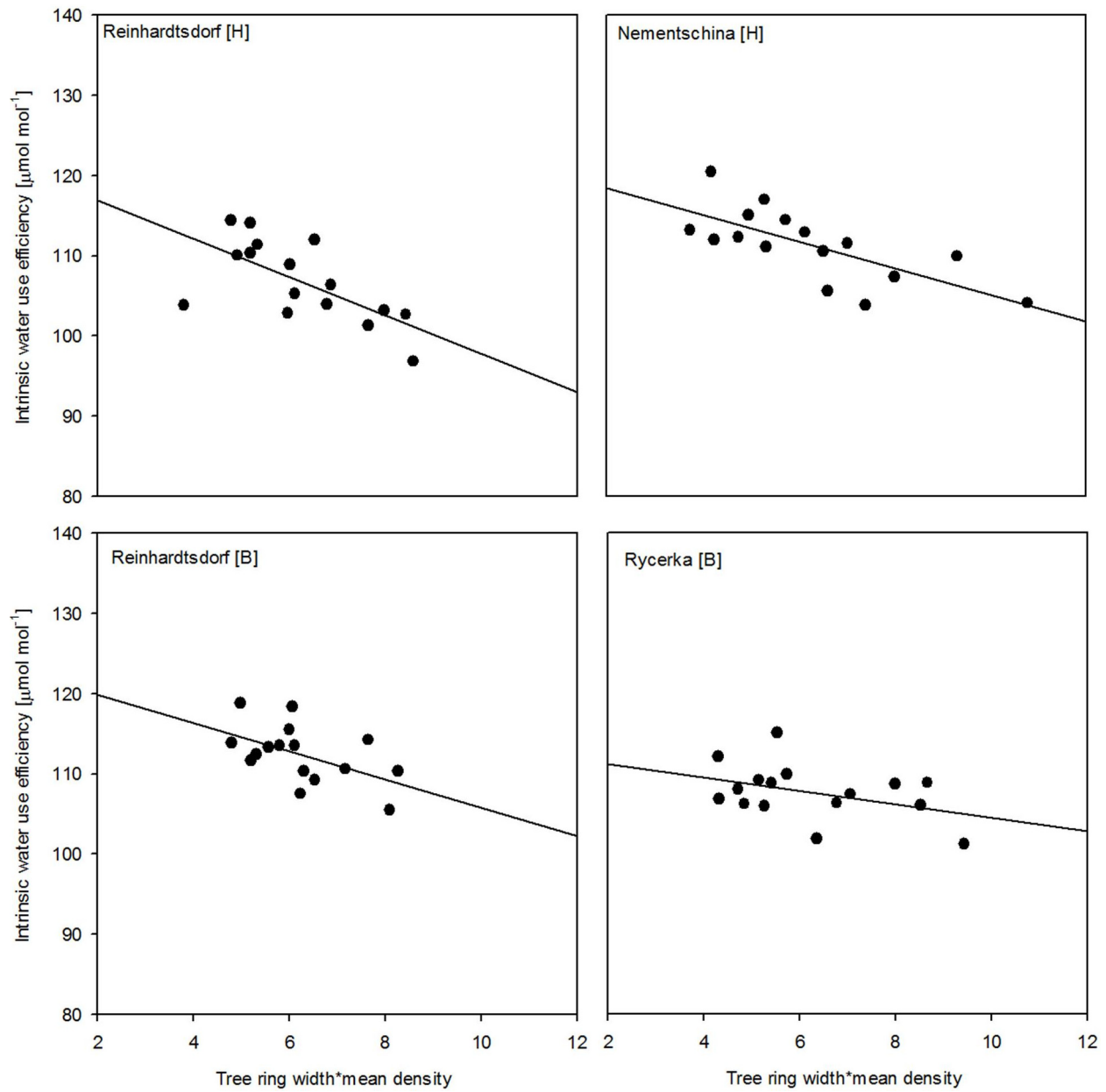

Figure 4. Trends of water use efficiency against productivity as a product of tree-ring width and annual mean density for the respective sites and provenances. 


\section{Discussion}

Here we show that $W_{U E}$ can be used as an indicator for stress experienced by mature trees. This is in line with the findings by Linares and Camarero [26], who found that more stressed trees exhibited higher $\mathrm{WUE}_{\mathrm{i}}$ values. The combination with a productivity indicator allows the comparison of different provenances and individuals.

MEWD showed an inhomogeneous response of individual trees which aligns with the findings of Sanvill and Sandels [27], stating that $63 \%$ of the variation in wood density is due to inter-tree effects while only $12 \%$ is due to competition. However, the predominating strong increase of MEWD in the last ten years, combined with a general reduction in annual growth indicates stress. As increasing earlywood density is a sensitive indicator of water deficit [28] and knowing the environmental conditions, we expected a response to drought. According to MEWD and annual tree-ring width, the Rheinhardtsdorf provenance in Hohenleipisch experienced the most adverse growth conditions, with Nementschina at the same site following closely. In Borstendorf, the more favourable site, the Reinhardsdorf provenance showed a very mixed response while Rycerka as the most placid provenance showed no response

In our study, WUE $\mathrm{i}_{\mathrm{i}}$ increases over the period from 1994 to 2012 in three of the four cases. This increase has often been attributed to rising levels of atmospheric $\mathrm{CO}_{2}$ [29]. Additionally, this rise in $\mathrm{CO}_{2}$ is linked to a positive growth response called $\mathrm{CO}_{2}$ fertilisation [4]. This effect is continuously questioned as omitting other climatic and environmental preconditioning factors [30] which we could confirm in the comparison of the Reinhardtsdorf provenance. Here a significant difference in the mean and range of $\mathrm{WUE}_{\mathrm{i}}$ differentiates the two sites. Furthermore, the width of fluctuation is lower in Borstendorf with intermediate but quite equally distributed rainfall throughout the year. While a negative relationship between annual precipitation and $W_{U E}$ is described for ecosystems in China [31], the difference in annual rainfall was smaller in our study. Nevertheless, years of higher water deficit (e.g., 2003) saw an increase in $W_{U} E_{i}$ for all samples confirming a plot and provenance specific response. Additionally, other factors such as deposition can influence WUE $\mathrm{i}_{\mathrm{i}}$ [32] and annual growth. Our two plots are and have been in a high deposition area since planting and thus obtain a continuous exposure to sulphur and nitrogen deposition ([14]. Therefore, we were unable to link deposition to $\delta^{13} \mathrm{C}$ values alas Martin et al. had previously done [33] and an influence can neither be confirmed nor rejected. The larger range might still imply an increased responsiveness which is possible for different Norway spruce provenances when faced with low precipitation, stagnating water in winter, and occasional flooding. This, rather than being due to a variation in genotype, seems to be a response to environmental conditions.

Most studies so far linked $W_{U} E_{i}$ to productivityonly in seedling studies. Peñuelas et al. [15] pooled their global analysis data from mature trees and stated that the increase in WUE $\mathrm{E}_{\mathrm{i}}$ was not linked to growth enhancement. This is in agreement with our findings on a much smaller scale, but with a higher resolution. We can highlight the difference between sites as well as provenances which could have cause the diffuse trend when analysing whole biomes. All sites except the Rycerka provenance showed a significant growth decrease. On the whole, we can confirm the increase in $\mathrm{WUE}_{\mathrm{i}}$ from the stable carbon isotope measurements from tree rings; we could not see an increase in productivity derived from annual tree-ring widths and density measurements. This study shows the high intra-population response breadth in $W_{U E}$ indicating a different phenotypic plasticity of the individual but also highlights the significant role of the local environmental.

Supplementary Materials: The following are available online at www.mdpi.com/1999-4907/7/12/296/S1, Figure S1: Overview of the sampling locations in Hohenleipisch and Borstendorf (triangle) as well as the source of origin of the respective provenances (filled circle), Table S1: Overview of the sampling sites with the different proveniences; altitude, mean annual temperature, and annual precipitation at their site of origin are given, Figure S2: Average annual basal area increment of all sampled trees at the two sites; showing the significantly higher growth at Borstendorf. 
Acknowledgments: This study was part of the project Bestimmung der Anpassungsfähigkeit von Fichten-(Picea abies [L.] Karst.)-Beständen für den Anpassungsprozess der sächsischen Forstwirtschaft an Klimaänderungen funded by the Saxonian State Forest in 2012. We thank the two anonymous reviewers for their constructive comments on an earlier draft of this manuscript.

Author Contributions: T.S. wrote the paper and analysed the data; W.B. designed the study, sampled the sites, and analysed the data; I.H. and B.G. were responsible for the isotopic and density analysis, respectively; H.W. conceived and designed the experiments.

Conflicts of Interest: The authors declare no conflict of interest.

\section{References}

1. Fardusi, M.J.; Ferrio, J.P.; Comas, C.; Voltas, J.; de Dios, V.R.; Serrano, L. Intra-specific association between carbon isotope composition and productivity in woody plants: A meta-analysis. Plant Sci. 2016, 251, 110-118. [CrossRef] [PubMed]

2. Norby, R.J.; Delucia, E.H.; Gielen, B.; Calfapietra, C.; Giardina, C.P.; King, J.S.; Ledford, J.; McCarthy, H.R.; Moore, D.J.; Ceulemans, R. Forest response to elevated $\mathrm{CO}_{2}$ is conserved across a broad range of productivity. Proc. Natl. Acad. Sci. USA 2005, 102, 18052-18056. [CrossRef] [PubMed]

3. Morgan, J.A.; Pataki, D.E.; Körner, C.; Clark, H.; Del Grosso, S.J.; Grünzweig, J.M.; Knapp, A.K.; Mosier, A.R.; Newton, P.C.D.; Niklaus, P.A.; et al. Water relations in grassland and desert ecosystems exposed to elevated atmospheric $\mathrm{CO}_{2}$. Oecologia 2004, 140, 11-25. [CrossRef] [PubMed]

4. Wullschleger, S.D.; Post, W.; King, A. On the potential for a $\mathrm{CO}_{2}$ fertilization effect in forests: Estimates of the biotic growth factor based on 58 controlled-exposure studies. In Biotic Feedbacks in the Global Climatic System; Woodwell, G.M., Mackenzie, F.T., Eds.; Oxford University Press: New York, NY, USA, 1995; pp. 85-107.

5. Körner, C.; Asshoff, R.; Bignucolo, O.; Hättenschwiler, S.; Keel, S.G.; Peláez-Riedl, S.; Pepin, S.; Siegwolf, R.T.W.; Zotz, G. Carbon Flux and Growth in Mature Deciduous Forest Trees Exposed to Elevated $\mathrm{CO}_{2}$. Science 2005, 309, 1360-1362. [CrossRef] [PubMed]

6. HÄTtenschwiler, S.; Miglietta, F.; Raschi, A.; KÖRner, C. Thirty years of in situ tree growth under elevated $\mathrm{CO}_{2}$ : A model for future forest responses? Glob. Chang. Biol. 1997, 3, 463-471. [CrossRef]

7. Pastor, J.; Post, W. Response of northern forests to $\mathrm{CO}_{2}$-induced climate change. Nature 1988, 334, 55-58. [CrossRef]

8. Morison, J.I.L. Sensitivity of stomata and water use efficiency to high $\mathrm{CO}_{2}$. Plant Cell Environ. 1985, 8, 467-474. [CrossRef]

9. Keenan, T.F.; Hollinger, D.Y.; Bohrer, G.; Dragoni, D.; Munger, J.W.; Schmid, H.P.; Richardson, A.D. Increase in forest water-use efficiency as atmospheric carbon dioxide concentrations rise. Nature 2013, 499, 324-327. [CrossRef] [PubMed]

10. Kwak, J.-H.; Lim, S.-S.; Lee, K.-S.; Viet, H.D.; Matsushima, M.; Lee, K.-H.; Jung, K.; Kim, H.-Y.; Lee, S.-M.; Chang, S.X. Temperature and air pollution affected tree ring $\delta^{13} \mathrm{C}$ and water-use efficiency of pine and oak trees under rising $\mathrm{CO}_{2}$ in a humid temperate forest. Chem. Geol. 2016, 420, 127-138. [CrossRef]

11. Bert, D.; Leavitt, S.W.; Dupouey, J.-L. Variations Of Wood $\Delta 13$ c And Water-Use Efficiency Of Abies Alba During The Last Century. Ecology 1997, 78, 1588-1596.

12. Rydval, M.; Wilson, R. The impact of industrial $\mathrm{SO}_{2}$ pollution on north Bohemia conifers. Water Air Soil Pollut. 2012, 223, 5727-5744. [CrossRef]

13. Meesenburg, H.; Ahrends, B.; Fleck, S.; Wagner, M.; Fortmann, H.; Scheler, B.; Klinck, U.; Dammann, I.; Eichhorn, J.; Mindrup, M.; et al. Long-term changes of ecosystem services at Solling, Germany: Recovery from acidification, but increasing nitrogen saturation? Ecol. Indic. 2016, 65, 103-112. [CrossRef]

14. Schmitz, A.; Sanders, T.G. Deposition. 2016. Available online: http://blumwald.thuenen.de/level-ii/ auswertungen/deposition/ (accessed on 30 August 2016).

15. Peñuelas, J.; Canadell, J.G.; Ogaya, R. Increased water-use efficiency during the 20th century did not translate into enhanced tree growth. Glob. Ecol. Biogeogr. 2011, 20, 597-608. [CrossRef]

16. Monclus, R.; Dreyer, E.; Villar, M.; Delmotte, F.M.; Delay, D.; Petit, J.-M.; Barbaroux, C.; Le Thiec, D.; Bréchet, C.; Brignolas, F. Impact of drought on productivity and water use efficiency in 29 genotypes of Populus deltoides $\times$ Populus nigra. New Phytol. 2006, 169, 765-777. [CrossRef] [PubMed] 
17. Farquhar, G.D.; Hubick, K.T.; Condon, A.G.; Richards, R.A. Carbon Isotope Fractionation and Plant Water-Use Efficiency. In Stable Isotopes in Ecological Research; Rundel, P.W., Ehleringer, J.R., Nagy, K.A., Eds.; Springer: New York, NY, USA, 1989; pp. 21-40.

18. Farquhar, G.D.; Ehleringer, J.R.; Hubick, K.T. Carbon isotope discrimination and photosynthesis. Annu. Rev. Plant Biol. 1989, 40, 503-537. [CrossRef]

19. Eamus, D. The interaction of rising $\mathrm{CO}_{2}$ and temperatures with water use efficiency. Plant Cell Environ. 1991, 14, 843-852. [CrossRef]

20. Silva, L.C.; Horwath, W.R. Explaining global increases in water use efficiency: Why have we overestimated responses to rising atmospheric $\mathrm{CO}_{2}$ in natural forest ecosystems? PLoS ONE 2013, 8, e53089. [CrossRef] [PubMed]

21. Silva, L.C.; Anand, M. Probing for the influence of atmospheric $\mathrm{CO}_{2}$ and climate change on forest ecosystems across biomes. Glob. Ecol. Biogeogr. 2013, 22, 83-92. [CrossRef]

22. Schweingruber, F.H. Der Jahrring; Standort, Methodik, Zeit und Klima in der Dendrochronologie; Haupt: Bern, Switzerland, 1983; Volume 234.

23. Loader, N.; Robertson, I.; Barker, A.; Switsur, V.; Waterhouse, J. An improved technique for the batch processing of small wholewood samples to $\alpha$-cellulose. Chem. Geol. 1997, 136, 313-317. [CrossRef]

24. Wilson, A.; Grinsted, M. ${ }^{12} \mathrm{C} /{ }^{13} \mathrm{C}$ in cellulose and lignin as palaeothermometers. Nature 1977, 265, $133-135$. [CrossRef]

25. Schweingruber, F.; Fritts, H.; Bräker, O.; Drew, L.; Schär, E. The X-ray technique as applied to dendroclimatology. Tree-Ring Bull. 1978, 38, 61.

26. Linares, J.C.; Camarero, J.J. From pattern to process: Linking intrinsic water-use efficiency to drought-induced forest decline. Glob. Chang. Biol. 2012, 18, 1000-1015. [CrossRef]

27. Sanvill, P.; Sandels, A. The influence of early respacing on the wood density of Sitka spruce. Forestry 1983, 56, 109-120.

28. Bouriaud, O.; Leban, J.-M.; Bert, D.; Deleuze, C. Intra-annual variations in climate influence growth and wood density of Norway spruce. Tree Physiol. 2005, 25, 651-660. [CrossRef] [PubMed]

29. Polley, H.W.; Johnson, H.B.; Marino, B.; Mayeux, H. Increase in C3 plant water-use efficiency and biomass over Glacial to present $\mathrm{CO}_{2}$ concentrations. Nature 1993, 361, 61.

30. Mousseau, M.; Saugier, B. The Direct Effect of Increased $\mathrm{CO}_{2}$ on Gas Exchange and Growth of Forest Tree Species. J. Exp. Bot. 1992, 43, 1121-1130. [CrossRef]

31. Yu, G.; Song, X.; Wang, Q.; Liu, Y.; Guan, D.; Yan, J.; Sun, X.; Zhang, L.; Wen, X. Water-use efficiency of forest ecosystems in eastern China and its relations to climatic variables. New Phytol. 2008, 177, 927-937. [CrossRef] [PubMed]

32. McLaughlin, S.B.; Nosal, M.; Wullschleger, S.D.; Sun, G. Interactive effects of ozone and climate on tree growth and water use in a southern Appalachian forest in the USA. New Phytol. 2007, 174, 109-124. [CrossRef] [PubMed]

33. Martin, B.; Bytnerowicz, A.; Thorstenson, Y.R. Effects of air pollutants on the composition of stable carbon isotopes, $\delta^{13} \mathrm{C}$, of leaves and wood, and on leaf injury. Plant Physiol. 1988, 88, 218-223. [CrossRef] [PubMed]

(C) 2016 by the authors; licensee MDPI, Basel, Switzerland. This article is an open access article distributed under the terms and conditions of the Creative Commons Attribution (CC-BY) license (http://creativecommons.org/licenses/by/4.0/). 